\title{
REPERCUSSIONS OF MARITAL INFIDELITY IN MALAYSIA: A LEGAL RESPONSE
}

\author{
Roslina Che Soh@ Yusof* \\ Nora Abdul Hak** \\ Noraini Mohd Hashim ${ }^{* * *}$ \\ Muhammad Helmi Md. Said ${ }^{* * * *}$
}

\begin{abstract}
In today's modern society, marital infidelity has become a dangerous threat to married life. Married couples are seen to be 'comfortable' in engaging in relationships with third parties. Such a trend has greatly contributed to the breakdown of marriages and subsequently led to the increase in the number of divorces and thus threatening the family institution. There are diverse causes for the prevalence of marital infidelity and this includes marriage boredom, unrealistic expectations, conflicts and misunderstandings between the husband and the wife. Although the seriousness of the affairs is widely recognized but marital infidelity is not considered as an offence in many jurisdictions including Malaysia. The objective of this article is to discuss the legal repercussions of marital infidelity in Malaysia and to consider whether existing legal solutions through the enforcement of law is an adequate mechanism to curb this social problem. The methodology adopted in this study is based on the content analysis of reports, case laws, leading textbooks and journal articles. The article is significant as it addresses crucial concerns over the adequacy of existing laws relating to the protection of the marriage and family institutions in Malaysia. The article is concluded with a series of recommendations and suggestions
\end{abstract}

* Law lecturer at Ahmad Ibrahim Kulliyyah of Laws, International Islamic University Malaysia. Email: roslinac@iium.edu.my.

** Law lecturer at Ahmad Ibrahim Kulliyyah of Laws, International Islamic University Malaysia. Email: ahnora@iium.edu.my.

*** Law lecturer at Ahmad Ibrahim Kulliyyah of Laws, International Islamic University Malaysia. Email: norainim@iium.edu.my.

**** Law lecturer at Faculty of Law, National University Malaysia. Email: mhelmisaid@ukm.edu.my.

The authors would like to thank other members of the research team for their contributions to the writing of this article. 
for improvements in existing law through appropriate legal mechanisms so as to curb the issue of marital infidelity in order to preserve the wellbeing of the family institution as a whole.

Keywords: infidelity in marriage, protection of the family institution, legal repercussions of infidelity, status of infidelity in Malaysia.

\section{KESAN KECURANGAN DALAM PERKAHWINAN DI MALAYSIA: SUATU TINDAKBALAS UNDANG-UNDANG \\ ABSTRAK}

Kecurangan dalam perkahwinan telah menjadi satu kebiasaan yang merbahaya dan mengancam kehidupan berkeluarga. Perbuatan ini berpotensi untuk memusnahkan perkahwinan dan menyebabkan peningkatan kadar perceraian dalam masyarakat. Ini kerana ia menandakan terdapat masalah hubungan antara pasangan. Terdapat pelbagai faktor yang menyebabkan curang dalam perkahwinan berlaku dalam masyarakat kita hari ini. Antara faktor yang menyebabkan curang dalam perkahwinan berlaku ialah bosan dalam perkahwinan, harapan yang tidak realistik, konflik dan salah faham antara satu sama lain. Seperti dalam banyak bidang kuasa lain, curang dalam perkahwinan bukanlah merupakan kesalahan di bawah undang-undang di Malaysia tetapi terdapat beberapa remedi atau cara yang boleh digunakan untuk mengurangkan kemungkinan berlakunya masalah tersebut. Objektif makalah ini adalah untuk membincangkan kesan undang-undang terhadap aktiviti kecurangan dalam perkahwinan di Malaysia dan sama ada penyelesaian melalui penguatkuasaan undang-undang adalah mekanisme yang mencukupi untuk membendung masalah ini. Metodologi yang digunakan dalam makalah ini adalah berdasarkan analisis kandungan laporan kes, buku teks dan makalah jurnal yang terkemuka. Makalah ini adalah penting kerana ia membincangkan perkara yang utama dengan merujuk kepada undang-undang semasa yang berkaitan dengan perlindungan perkahwinan dan institusi kekeluargaan di Malaysia. Kesimpulan yang dibuat termasuk beberapa saranan untuk penambahbaikan dalam mencari mekanisme perundangan yang sesuai untuk membendung isu kecurangan dalam perkahwinan demi melihara institusi kekeluargaan secara keseluruhan.

Kata kunci: kecurangan dalam perkahwinan, kemusnahan institusi kekeluargaan, kesan dalam perundangan Malaysia. 


\section{INTRODUCTION}

\section{Marital Infidelity defined}

Marital infidelity is one of the great challenges affecting married life and threatening family institutions. In spite of its obvious danger, most jurisdictions in the world do not consider it as a specific offence and fail to provide specific laws to control this perplexing problem. There is no universal definition of infidelity as it varies within cultures and depends on the type of relationship that exists between people. ${ }^{1}$ Five, Weeks, and Gambescia for instance, proposed that, "most committed relationships are characterized by an explicit or implicit commitment regarding intimacy, including both sexual and emotional fidelity to one's partner". ${ }^{2}$ They define infidelity as "a betrayal of this implied or stated commitment regarding intimate exclusivity. With infidelity, emotional and/or sexual intimacy is shared with someone outside of the primary relationship without the consent of the other partner". 3 Meanwhile, Blow and Hartnett stated that, infidelity is defined in a myriad of ways and can comprise a number of activities including: "having an affair," "extramarital relationship," "cheating," "sexual intercourse with a third party," "having oral sex," "kissing," "fondling," "having emotional connections that are beyond friendships," "friendships," "internet relationships," "pornography use," and others. ${ }^{4}$ In short, marital infidelity is not only confined to sexual or physical acts of intimacy but may vary according to differing cultures and type of relationships.

1 Review of studies on infidelity (by Bahareh Zare) 2011 3rd International Conference on Advanced Management Science IPEDR vol.19 (2011) (C) (2011) IACSIT Press, Singapore. http://www.ipedr.com/vol19/34ICAMS2011-A10054.pdf p. 182.

2 Fife, S.T., Weeks, G.R., \& Gambescia, N., "Treating Infidelity: An Integrative Approach," The family journal: counseling and therapy for couples and families 16 (2008): 316. DOI: 10.1177/1066480708323205

3 Ibid.

4 Blow, A.J. \& Hartnett, "Infidelity in committed relationships I: A methodological review," Journal of Marital and Family Therapy 31(2) (2005): 183 . 


\section{Types of Marital Infidelity}

A preponderance of the literature divided infidelity to more specific categories including sexual infidelity, emotional infidelity, combined sexual and emotional infidelity and internet infidelity. Dewall et al for instance, classified infidelity into 3 types, which include, sexual infidelity, emotional infidelity and full investment infidelity. In reference to internet infidelity, Beatriz opined that it is a process whereby individuals involved in a long-term committed relationship seeks "computer synchronous interactive contact with the other partner". ${ }^{5}$ Sexual infidelity is not just a relationship with someone outside the marriage that is purely sexual in nature. It can also include activities where there is no physical contact at all, such as telephone or online sex since the offender is seeking sexual pleasure outside of the marriage. ${ }^{6}$

In general, physical and emotional infidelities are often the most highly recognized forms of infidelity. Nevertheless, internet or cyber infidelity is becoming increasingly prevalent. ${ }^{7}$ According to Whitty, the effects of an online affair can be "almost as severe as sexual intercourse". ${ }^{8}$ Smart phones and the internet are seen to be convenient mediums for anyone to be engaged in marital infidelity. Thus, not only

5 B.L.A. Mileham (2007): Online infidelity in Internet chat rooms: an ethnographic exploration, Computers in Human Behavior 23 (2007) 1131: 12 .

6 DeWall, C. N., Lambert, N. M., Slotter, E. B., Pond, R. S., Jr., Deckman, T., Finkel, E. J., Luchies, L. B., \& Fincham, F. D. (2011). So far away from one's partner, yet so close to romantic alternatives: Avoidant attachment, interest in alternatives, and infidelity. Journal of Personality and Social Psychology, 101(6), 1302-1316:1302. https://doi.org/10.1037/a0025497).

7 Henline, B. H., Lamke, L. K., \& Howard, M. D. (2007). Exploring perceptions of online infidelity. Personal Relationships, 14(1), 113128:113. https://doi.org/10.1111/j.1475-6811.2006.00144.x.

8 Whitty, M.T. "The realness of cybercheating: men's and women's representations of unfaithful Internet relationships," Social science computer review, 23(2005): 57, as cited in Schonian, Sarah, "Perceptions and Definition of Infidelity: A Multimethod Study" UNLV Theses, Dissertations, Professional Papers, and Capstones. (2013) 2026.1-110:5. http://dx.doi.org/10.34917/5363941http://digitalscholarship.unlv.edu/the sesdissertations/2026. 
does modern technology provide more possibilities for communication but it also creates avenues for engaging in unfaithful relationships with others. ${ }^{9}$

\section{Reasons for Infidelity}

Research on infidelity shows that there are various reasons for engaging in relationships outside marriage. Drigotas et al for instance, divided the reasons for infidelity into five categories:

a) sexual satisfaction, where there is a search for sexual variety or due to sexual incompatibility with the partner;

b) emotional satisfaction, in which the focus is on emotional satisfaction with a new relationship;

c) social context, including variables such as opportunity or physical separation of the partner;

d) rules and attitudes related to social norms, such as sexual permissiveness; and

e) revenge/hostility associated with the desire to retaliate for betrayal suffered. ${ }^{10}$

In an earlier research by Roscoe et al on sexuality issues in infidelity, it was found that the need for sexual variety and sexual income possibility as common reasons for engaging in infidelity. ${ }^{11}$ Buss \& Shackelford and Roscoe et al in their studies on the emotional satisfaction of married couples, concluded that the overall marital dissatisfaction is the main reason for infidelity. ${ }^{12}$ Buss \& Shackelford

9 Schonian, Sarah, "Perceptions and Definition of Infidelity: A Multimethod Study" UNLV Theses, Dissertations, Professional Papers, and Capstones. (2013) 2026.1-110:5. http://dx.doi.org/10.34917/5363941 http://digitalscholarship.unlv.edu/thesesdissertations/2026.

10 Drigotas, S. M., Safstrom, C. A., \& Gentilia, T. (1999). An investment model prediction of dating infidelity. Journal of Personality and Social Psychology, 77(3), 509-524:509.

11 Buunk, B. 1980. Extramarital sex in the Netherlands Motivations in social and marital context. Journal Of Family And Economic Issues 3 (1): 28.

12 Buss D.M, \& Shackelford. T.K (1997), Susceptibility to Infidelity in the First Year of Marriage. Journal of Research in Personality 31, 193-221: 194. 
also added that, "infidelity as a revenge is traditionally considered as common reason for being unfaithful among married couples". ${ }^{13}$

\section{Marital Infidelity from an Islamic Perspective}

In Islam, al-Qur'an has defined marriage as mithaq, ${ }^{14}$ which means a solemn covenant. A nikah is a marriage contract between a husband and wife in the presence of human witnesses and under the vigilance of Allah, the All-Seeing Lord, the Master of the universe. When one commits infidelity or cheats in his/her marriage, the act not only violates the terms of the contract but also the law of Allah. When one cheats in marriage, he or she has to face the wrath of Allah, both in this world and the hereafter. In an authentic Hadith, the Prophet of Allah s.a.w said, "The one who cheats is not one of us" ${ }^{15}$ This Hadith makes it absolutely clear that the one who cheats a person, whether a Muslim or a non-Muslim, what more his/her own spouse does not follow the teachings of Prophet s.a.w and is not considered fit to be recognized as his followers. Hence, the repercussions for the act of infidelity extends to the Hereafter. As mentioned above, the act of cheating is a clear contravention of a divine covenant of Islam, its repercussions goes beyond imagination. Besides the repercussion to be face in the world and hereafter (if the person did not repent), the parties may end their marriage due to the ground of infidelity by way of dissolution of marriage.

Hence, it is clear that marital infidelity is one of the major sins in Islam. Numerous authorities in the Islamic texts prohibits such act be it a physical or sexual and emotional infidelity. In the Qur'an Allah says:

Do not go near adultery, surely it is an indecency, and an evil way [of fulfilling sexual urge]. ${ }^{16}$

The verse signifies the importance of keeping oneself from indulging in any acts or conducts which may lead to adultery and resulting in the breakdown of the family institution. Fornication and adultery have also

\footnotetext{
13 Ibid.

14 Sahih Muslim, Kitab al-Hajj, vol.2, p.165.

15 Sahih Muslim, Kitab Aqidah, p. 164.

16 Surah al-Isra (17):32. The Holy Qur'an. Translation by Abdullah Yusuf Ali. Saba Islamic Media: Kuala Lumpur.
} 
severely been condemned in the hadiths of the Prophet. While describing the believers, the Qur'an says,

The believers are... those who protect their sexual organs except from their spouses... Therefore, whosoever seeks more beyond that [in sexual gratification], then they are the transgressors. ${ }^{17}$

Again, Allah says, regarding His true believers:

Those who invoke not, with Allah, any other god, nor slay such life as Allah has made sacred except for just cause, nor commit fornication; - and any that does this deserves punishment. ${ }^{18}$

The Prophet said: "The fornicator does not commit fornication while he is a believer. ${ }^{19}$ " In another hadith, it is narrated that a young man once came to our Prophet S.A.W and said: "O, Messenger of Allah give me a permission to commit fornication." The Companions were angry at the way that young man who dared to ask such a thing from the Prophet S.A.W, but the Prophet S.A.W did not grow angry and immediately asked him:

Would you like a man to fornicate with your mother?" The young man replied: "No." The Prophet (peace be upon him) said: "Hence other people do not like it for their mothers. Would you like it for your daughter?" The man said: "No." The Prophet S.A.W said: "Hence people do not like it for their daughters.... ${ }^{20}$

Aside from the intense prohibition from even approaching zina or adultery, in Islam, the act is a heinous crime and if proven will make the offenders liable to the punishment of stoning to death. ${ }^{21}$

17 Surah al-Mu'minun (23): verses 5-6, The Holy Qur'an. Translation by Abdullah Yusuf Ali.

18 Surah al-Furqan (25): verse 68, The Holy Qur'an. Translation by Abdullah Yusuf Ali.

19 Sahîh Muslim, Kitab al-Iman, Hadith No. 104.

20 Musnad Ahmad 21708 available at dailyhadithonline/2014/05/09/zinaadulter-like-sister/.

21 This is based on the hadith of Abdullah b. Abbas who reported that Umar b. Khattab sat on the pulpit of Allah's Messenger s.a.w and said: Verily Allah sent Muhammad s.a.w with truth and He sent down the Book upon him and the verse of stoning was included in what was sent 


\section{LEGAL RESPONSE TO MARITAL INFIDELITY IN MALAYSIA}

\section{Family Law}

Most of the research findings concluded that adultery is one of the common causes of marital infidelity. In many jurisdictions, including Malaysia, adultery is considered as one of the facts that contribute to the marital breakdown. ${ }^{22}$ In Malaysia, The National Population and Family Development Board (LPPKN) through the Fifth Malaysia Population and Family Survey (KPKM-5), found that marital infidelity was in the second, after the lack of understanding, which became the main cause of divorce among couples being studied. ${ }^{23}$ KPKM-5 found that 56.2 per cent of the men surveyed acknowledged that there was no understanding of the cause of divorce, while 11.8 per cent divorced because of marital infidelity. Among women, 20.5 per cent admitted their divorce was due to marital infidelity, while 38.0 percent due to lack of understanding. ${ }^{24}$

\section{i) Non-Muslims}

The Law Reform (Marriage \& Divorce) Act 1976 (LRA), the law which govern the family matters of the non-Muslims, clearly provides that adultery is one of the alleged facts which may contribute to the

down to him. We recited it, retained it in our memory and understood it. Allah's Messenger s.a.w awarded the punishment of stoning to death (to the married adulterer and adulteress, and after him, we also awarded the punishment of stoning, I am afraid that with the lapse of time, the people (may forget it) and may say: We do not find the punishment of stoning in the Book of Allah, and thus go astray by abandoning this duty prescribed by Allah. Stoning is a duty laid down in Allah's Book for married men and women who commit adultery when proof is established, or if there is pregnancy or a confession. Sahih Muslim, Kitab al-Hudud Book No. 17, Hadith No. 4194. Available at iium.edu.my/deed/hadith/muslim/017_smt.html.

22 See for instance, section 95 of the Women Charter of Singapore.

23 Laporan Penemuan Utama: Kajian Penduduk dan Keluarga Malaysia Kelima (KPKM-5)", Lembaga Penduduk dan Pembanguan Keluarga Negara, accessed March 27, 2018, http://www.lppkn.gov.my/index.php/pusat-sumber/2016-02-26-02-2515/2016-03-04-00-42-00/file. Ibid. 
breakdown of the marriage and the party who applies for the divorce must also prove to the court that he or she finds it intolerable to live with the respondent. ${ }^{25}$ Previously, adultery was considered as a matrimonial offence and for a decree of divorce to be declared by a court, the standard of proof of adultery must be beyond reasonable doubt as in criminal cases. However, at present, the underlying rational for a divorce is based on the concept of irretrievable breakdown of marriage rather than on the fact that one spouse has committed a matrimonial offence. Proceedings for divorce are civil in nature and these factors would appear to indicate that the standard of proof is that on a balance of probabilities. ${ }^{26}$ The LRA also gives the right to the petitioner to sue for damages against the third party with whom the respondent is involved with in the adulterous relationship. However, the damages are only in pecuniary form and shall not include any exemplary or punitive elements. ${ }^{27}$ The rationale is since adultery is not a crime, monetary damages is deemed sufficient to penalize the parties involved in the illicit relationship.

In the case of Tan Wat Yan $v$ Kong Chiew Meng \& Anor, ${ }^{28}$ the wife had alleged adultery on the part of her husband, which had been going on for the last 7-8 years and thus she sought for a divorce. She also sought damages against the co-respondent. The allegation on adultery was not challenged since the respondent did have three children by the co-respondent. Mokhtar Sidin J. stated that he was satisfied that the petitioner did not condone the act of adultery and that she could not possibly continue living with the respondent, therefore the divorce was granted, and damages were also ordered against the corespondent. In Leow Kooi Wah v Ng Kok Seng Philip \& Anor ${ }^{29}$ the court held that that since the co-respondent admitted the adultery, the petitioner was eligible to damages against the co-respondent. The quantum of such damages will depend on all the circumstances of the case and though compensatory, are not restricted to pecuniary loss. The co- respondent knew that the petitioner and respondent were married when she committed adultery with him. That was an aggravating factor

\footnotetext{
$25 \quad$ Section 53 and 54.

26 Tan Cheng Han, Matrimonial Law in Singapore \& Malaysia, 1994, Singapore, Butterworths Asia, at 129.

27 See section 58 \& 59 LRA 1976.

28 Tan Wat Yan v Kong Chiew Meng \& Anor [1994] 3 CLJ 676.

29 Leow Kooi Wah v Ng Kok Seng Philip \& Anor [1995]1MLJ 852.
} 
to be taken into account by the Court. The value to be paid to the spouse and the injury to the aggrieved spouse's feelings vary from case to case.

In matters pertaining to ancillary reliefs, adultery may give certain impact on the order and assessment of maintenance for the wife. Adultery is one of the factors that may absolve the husband's duty to maintain the wife during marriage and upon divorce. Section 5 of the Married Women and Children Maintenance Act 1950 and section 82 of the LRA clearly provides for the cessation of maintenance for the wife if the court is satisfied with the evidence showing that she is living in adultery. ${ }^{30}$ Living in adultery has been defined in the case of Rajalashmi $v$ Sinniah $^{31}$ as having been involved in a series of guilty conduct of adultery. ${ }^{32}$ Thus, it is not sufficient for a husband to claim that his duty to maintain is absolved if the wife had committed the adultery only once. In addition, the court, when assessing the amount of maintenance, will also consider which party has contributed to the breakdown of the marriage. ${ }^{33}$ Thus, if the husband for instance is guilty of committing adultery, which later leads to the marriage breakdown, the court may increase the amount of maintenance order. On the other hand, if the wife is the guilty party, no maintenance order shall be made for her. In the case of Lee Yu Lan v Lim Thain Chye, ${ }^{34}$ the judge agreed that the court must take into account the responsibility on the part of the husband for the breakdown of the marriage before deciding on the amount of maintenance to be paid by him. Similarly, in the case of Yap Kim Swee v Leong Hung Yin, ${ }^{35}$ the court dismissed the wife's claim for maintenance upon divorce as it was proven that she had contributed to the breakdown of the marriage due to her adulterous conduct.

Unlike maintenance, the law generally does not deprive the adulterer spouse from obtaining the custody of children or getting some

30 Married Women and Children Maintenance Act 1950 governs matters pertaining to maintenance during marriage, while LRA provides for maintenance of wife after divorce.

$31 \quad$ Rajalashmi v Sinniah [1973] 2 MLJ 233.

32 Raja Azlan Shah J stated that "The words "living in adultery" in their ordinary and natural meaning are susceptible of only one meaning i.e., to a course of guilty conduct rather than to an isolated act of adultery or occasional lapses from virtue."

33 Section 78 of LRA 1976.

$34 \quad$ Lee Yu Lan v Lim Thain Chye [1984] 1 MLJ 36.

35 Yap Kim Swee v Leong Hung Yin [1989] 3 MLJ 55. 
portion of the matrimonial properties. In legal disputes concerning the custody of children, the primary concern of courts is to provide for the "best interests of children". ${ }^{36}$ While the judicial inquiry varies depending on the legal context and while other factors may also be legally significant, if the court reaches the merits, it invariably tries to determine what custody or visitation arrangement will serve the best interests of the children. The governing principle of best interest of the child at least encourages courts to focus on all of the available evidence regarding the children's needs and vulnerabilities and to consider all available evidence about parental qualities, behavior, and circumstances that are likely to be either harmful or helpful to the child's development and ability to experience a healthy, happy life. ${ }^{37}$ Thus, the admission of evidence regarding parental infidelity in custody cases is that the court must start with some rule or assumption about whether parental infidelity generally is harmful to children and will jeopardise the best interest of the child. ${ }^{38}$ This principle is echoed in the Federal Court case of Teh Eng Kim V Yew Peng Siong, ${ }^{39}$ where Arulanandom J. had cited the judge's statement of an English case of $H v H$ and $C$ [1969] 1 All ER 262 on this matter. He said:

...Just as parental rights are overridden, criticisms of the conduct of parents because they transgressed conventional moral code also have no place in custody proceedings except in as far as they reflect upon the parent's fitness to take charge of the children. As Salmon L.J. said in a custody case: "I do not myself think that, whether this marriage broke up because of the fault of the father or mother or both of them, is of any consequence whatsoever. But I am bound to say that what impressed me is the fact, not that this mother committed adultery with another man in May 1966 but that she went off to live with him leaving the child behind... ${ }^{40}$

36 Section 88(2) of LRA 1976 inter alia provides that “....in deciding in whose custody a child should be placed the paramount consideration shall be the welfare of the child...".

37 Lynn D. Wardle, "Parental Infidelity and the "No-Harm" Rule in Custody Litigation," Cath. U. L. Rev, 52 (2003):81. Available at: http://scholarship.law.edu/lawreview/vol52/iss 1/4.

38 Ibid.

39 Teh Eng Kim V Yew Peng Siong [1977] 1 MLJ 234.

40 Ibid at page 8 . 
The same principle has been adopted in Khoo Chee Nee $v$ Lubin Chiew Pau Sing ${ }^{41}$ in which the court concluded that the wife's admission as to her dubious conduct of having sexual relationship with different men is not the general concern of the court in determining her custodial rights. What is important is, "the question of what exactly is the children being exposed to and whether it is contrary to their welfare". The judge further said that although adultery is frowned upon by the Malaysian society but by itself is not a sufficient ground to disqualify a mother from having custody of her children. ${ }^{42}$

The above cases have shown that in determining the custody of children after parental divorce, the court would only consider the adulterous conduct of one parent if it is proven that it would harm or jeorpardise the welfare of the child.

Regarding the distribution of the matrimonial property after divorce, the law similarly does not consider infidelity of one party as a factor in assessing the amount or portion of the property. Section 76 of LRA only mentioned three matters to be considered by the court, namely, the extent of contribution of either party or the debt incurred in acquiring the property during marriage and the interest of minor children. Thus, however good or bad the parties' conducts are, there is no such consideration to be taken by the court under this section.

\section{ii) Muslims}

In Islam, there are a few methods for married couple to end their marriage. Talaq ${ }^{43}$, khulu$^{\prime 44}$, ta $^{\prime} l i q,{ }^{45}$ and fasakh ${ }^{46}$ are commonly referred to indicate as the numerous methods of divorce that are

$41 \quad$ Khoo Chee Nee v Lubin Chiew Pau Sing 4 MLJ 7.

42 See also Shanmugam v Pitchamany and Anor (1976) 2 MLJ 222, Marina Nahulandran v Appiah Nahulandran and Anor 1 MLJ 137, Goh Kim Hwa $v$ Khoo Swee Huah 2 MLJ 156 and Winnie Young v William Lee Say Beng $1 M L J$ 123. For further details on the impact of adultery on custody of children, please refer to Daleleer Kaur Randawan \& Sheela Jayabalan, "The Implication of Adultery in Child Custody Cases in Malaysia", The Social Sciences 11 (Special Issue 6) (2016): 7183-7188.

43 Divorce, which is the right of husband alone to pronounce it.

44 Redemption divorce.

45 Conditional divorce.

46 Dissolution of marriage by judicial process based on grounds acceptable under Islamic law. 
prescribed by the Muslim jurists. However, in the case of infidelity, it is advisable to dissolve the marriage by way of talaq or fasakh as the divorce requires judicial sanction once the petitioner can prove that the marriage has irretrievably broken down due to the act of infidelity. In the case of talaq, according to hukum syara' the husband can repudiate the marriage by pronouncing the word talaq or its derivative. If the pronouncement is clear, the marriage is dissolved, as proof of intention is immaterial. ${ }^{47}$ Nevertheless in Malaysia, although legal recognition is given by the Shariah Court ${ }^{48}$ to the traditional method of divorce and allows it to be registered, the husband will be penalized first. ${ }^{49}$ By virtue of section 55A of Islamic Family Law (Federal Territories) Act 1984 (IFLA), to prevent the husband from pronouncing the talaq outside the court, any application for a divorce either from the husband or the wife, must be pronounced in the court. This is to ensure that the validity of the talaq is investigated in terms of its pronouncement and it is not for the court to question the grounds for the divorce.

Another way to end the marriage due to infidelity is by way of fasakh. Fasakh refers to an option ${ }^{50}$ exercised by the wife or husband to end her marriage through judicial process based on the grounds that are acceptable in Islamic law. This principle is extensively developed by the Muslim jurists based on the general rule of harm (darar) though they slightly differ on the details pertaining to the grounds for fasakh. All the states in Malaysia have standardised and uniformed the law governing divorce by fasakh by enabling both the wife and the husband to apply for the dissolution of marriage on the satisfaction of one or more of the grounds for fasakh under the Islamic family law of

47 The Muslim jurists do not require the presence of intention for a valid divorce as compared to the case of marriage.

48 Section 45 of IFLA 1984 clearly specifies the jurisdiction of the court to make order of divorce or an order pertaining to divorce or to permit husband to pronounce a talaq.

49 Section 124 of IFLA 1984.

50 The classical texts address fasakh as an option especially for the wife though the husband may also use this option on acceptable ground. See for example Ibn Qudamah in his text of al Mughni used the word option (khiyar) when dealing with the right to fasakh. Therefore, if this option is not exercised by the parties, no order of dissolution of marriage shall be made. See for example, Ibn Qudamah, (n/d) Al Mughni wa Sharh al Kabir, Dar al kutub al Arabi, p. 579. 
respective states. ${ }^{51}$ Originally, the law is meant for women, which are vulnerable to abuse especially in society where women's mobility is restrictive. After the amendment, the law gives equal opportunity for both genders, though the wife tends to benefit more from such provisions and the man has accorded with the right to divorce by talaq. Above all, the basis for the claim of fasakh is harm or darar and all major grounds for dissolution of marriage by fasakh discussed in classical texts are encapsulated into specific provisions. For the purpose of this article, the relevant provision is as follows:

52 (1) A woman married in accordance with Hukum Syara', shall be entitled to obtain an order for the dissolution of marriage or fasakh on any one or more of the following grounds, namely:

(h) that the husband treats her with cruelty, that is to say inter alia; habitually assaults her or make her life miserable by cruelty or conduct; or associates with women of evil repute or leads what, according to Hukum Syara', is an infamous life;

The above provision illustrates that the term cruelty has been widely defined as to include physical injury to the body, moral as well as property. However, mental injury seems to have been excluded from the list presumably associated with the difficulty to prove or to give wider discretion to the judge should there is an allegation involving mental or psychological violence. In the case of Zakhlina bt Khalid $v$ Noasmadi bin Abdullah ${ }^{52}$ the parties had been married in 1995 and registered it in Terengganu. The wife claimed for a fasakh divorce on the ground that the husband had treated her with cruelty and that he was having an affair with another woman. The learned judge, Mat Ropi Busu in allowing the application stressed that:

It is not the purpose of marriage in Islam to force parties to live in misery and cruelty in the marriage that they disliked. Cruelty in any form should be avoided. If particular marriage fails and its sacred aim and purpose could not be achieved, and instead results in harm, distress and difficulties among others, then it is appropriate that the marriage be dissolved.

51 With an exception to the state of Terengganu.

52 Zakhlina bt Khalid v Noasmadi bin Abdullah [2013] 3 ShLR 100. 
Marital infidelity on social media including misuse of Facebook and WhatsApp applications are among the contributing factors to divorce rates. ${ }^{53}$ Terengganu Syariah Chief Judge, Wan Mohd Zakri Wan Mohd said the use of social media could lead to doubts of couples who eventually wreaked havoc on divorce. ${ }^{54}$ Moreover, the misuse of the social media and organizing of school or university alumni such as gathering (reunion) programs has led to the dishonest act among the spouses of this country, resulting in divorce. ${ }^{55}$

The Shari'ah and the law in Malaysia has declared that it is the husband's responsibility to maintain his wife and children. But it is clearly provided that when a wife is proven committing infidelity in a marriage, she will disentitle to her rights to maintenance or nafkah as she is considered to have committed nusyuz ${ }^{56}$ or has unreasonably refused to obey the lawful wishes and commands of her husband. However, if she repents, she ceases to be nusyuz and will entitle to nafkah again. Besides losing her right to maintenance, she will also lose her rights to custody as provided in section 83 (b) of IFLA 1984 by her gross and open immorality. Nevertheless, there are no provision in the IFLA 1984 clearly specifying the repercussion if the husband commits infidelity.

As to the infidelity itself, there is no definite provision making it an offence. On the other hand, under the Syariah Criminal Offences

53 Nur Fazlizai Ali, Curang di Facebook, Whatsapp antara punca Perceraian," Astro Awani, January 19, 2018, accessed March 26, 2018, http://www.astroawani.com/berita-malaysia/curang-di-facebookwhatsapp-antara-punca-perceraian-166058.

54 Ibid.

55 Mohd Iskandar Ibrahim and Ilah Hafiz Aziz, "Main Kayu Tiga Punca Cerai," BH Online, August 15, 2017, accessed March 27, 2018, https://www.bharian.com.my/wanita/keluarga/2017/08/312402/mainkayu-tiga-punca-cerai.

56 Section 59(2). Subject to Hukum Syara' and confirmation by the Court, a wife shall not be entitled to maintenance when she is nusyuz, or unreasonably refuses to obey the lawful wishes or commands of her husband, that is to say, inter alia - $(a)$ when she withholds her association with her husband; $(b)$ when she leaves her husband's home against his will; or $(c)$ when she refuses to move with him to another home or place, without any valid reason according to Hukum Syara'. 
Act 1997 (ACT 559 (herein after known as SCOA 1997) provisions namely sexual intercourse out of wedlock, ${ }^{57}$ an act preparatory to sexual intercourse out of wedlock ${ }^{58}$ and khalwat (close proximity) ${ }^{59}$ can be used to take action against the parties concerned. For sexual intercourse committed by a husband or wife out of wedlock the penalties are fine not exceeding five thousand ringgit or imprisonment for a term not exceeding three years or to a whipping not exceeding six strokes or to any combination thereof. As an act for preparatory to sexual intercourse out of wedlock and khalwat, for both offences, the parties will be guilty of an offence and shall be liable to a fine not exceeding three thousand ringgit or to imprisonment for a term not exceeding two years or both.

\section{2) Criminal Law}

As been discussed above, marital infidelity or an adulterous conduct of one spouse is not considered as a crime in Malaysia. Nevertheless, the law specifically criminalizes the enticement or detention of a married woman, "with intent that she may have illicit intercourse. Section 498 of the Penal Code states:

Whoever takes or entices away any woman who is and whom he knows, or has reason to believe, to be the wife of any other man, from that man, or from any person having the care of her on behalf of that man, with intent that she may have illicit intercourse with any person, or conceals, or detains with that intent any such woman, shall be punished with imprisonment for a term which may extend to two years or with fine or with both.

57 Section 23(1) SCOA 1997: Any man performs sexual intercourse with a woman who is not his lawful wife. Section 23 (2) SCOA 1997: Any woman performs sexual intercourse with a man who is not his lawful husband.

58 Section 24 SCOA 1997.

59 Section 27 SCOA 1997:

Any

(a) Man, who is found together with one or more women not being his wife or mahram or,

(b) woman who is found together with one or more men not being his husband or mahram, in a secluded place or in a house or a room under circumstances which may give rise to suspicion that they were engaged in immoral act. 
The distinction between adultery and enticement is that in adultery, a woman may be a consenting party but under section 498 , she may be a subject of enticement against her own will. In practice, claim for enticement is rare as the Attorney General's chambers often decline to prosecute under section 498 viewing it as a private matter between a husband and wife. ${ }^{60}$ It is to be noted that the section only provides for enticement of a married woman but no similar prohibition against enticement of a married man. This is one of the criticisms posed on the section as it is considered to be gender biased. Another criticism is that it only blames the 'enticer' of the wife, and not the wife as well. Since the transgression only blames one party, in a situation where both parties are consenting, section 498 seems to be in direct breach of Article 8(1) and 8(2) of the Federal Constitution, which says that "all persons are equal before the law" and "there shall be no discrimination against citizens. ${ }^{61}$

\section{OTHER SELECTED JURISDICTIONS}

The majority of the countries in the world do not consider marital infidelity as an offence per se. However, if it involves sexual infidelity like adultery, some jurisdictions still regard it as a criminal offence. India for instance criminalised the act of adultery and punishes the wrongdoer with imprisonment up to 5 years or fine or with both. ${ }^{62}$ In United States of America, the law of adultery varies from one State to another. However, after the decision of a Supreme Court case in 2003,

60 "Divorce \& Matrimonial Law FAQS," Thomas Philip Advocates \& Solicitors, accessed March 27, 2018, http://www.thomasphilip.com.my/divorce-and-matrimonial-lawfaqs/adultery/.

61 Ding Jo Ann, "Defending a Victorian-era Law," The Nut Graph, November 17, 2009, accessed March 28, 2018. http://www.malaysianbar.org.my/legal/general_news/defending_a_victo rian_era_law.html.

62 According to Section 497 of Indian Penal Code, adultery means "Whoever has sexual intercourse with a person who is and whom he knows or has reason to believe to be the wife of another man, without the consent or connivance of that man, such sexual intercourse not amounting to the offence of rape, is guilty of the offence of adultery, and shall be punished with imprisonment of either description for a term which may extend to five years, or with fine, or with both. In such case, the wife shall not be punishable as an abettor." 
the validity of adultery law is under debate. ${ }^{63}$ Almost twenty states currently have statutes criminalizing adultery, fornication, or both. Most of those statutes were enacted in the 1800s and were vigorously enforced. In fact, enforcement of adultery and fornication statutes appears to have been commonplace until the 1940s and 1950s, when it abruptly tapered off. Since then, adultery has become a civil, rather than a criminal; matter in most jurisdictions; as such, criminal prosecutions for adultery have been largely replaced by divorce proceedings. ${ }^{64}$

In most part of the European Union, including England, Austria and Italy, adultery is not considered to be a criminal offence anymore. ${ }^{65}$ The European Union (EU) has condemned death penalty for adultery from time to time. Nevertheless, Islamic countries like Afghanistan, Nigeria, Pakistan, Yemen, Sudan, Saudi Arabia and Iran have provisions for death penalty as the maximum punishment for adultery, but the concept is deeply rooted in the traditional and religious view of Shariah. ${ }^{66}$

\section{CONCLUSIONS AND RECOMMENDATIONS}

Preservation of marriage is the key to a successful family life. Marital infidelity happens due to various reasons and even though it is only

63 Lawrence v. Texas 539 U.S. 558 (2003), as cited in JoAnne Sweeny, Undead Statutes: The Rise, Fall, and Continuing Uses of Adultery and Fornication Criminal Laws, Loyola University Chicago Law Journal, 46 (2014): 127-173.

64 Heather Brook, Conjugal Rites: Marriage and Marriage-Like Relationships Before, The Law 81 (2007), as cited in JoAnne Sweeny, ibid.

65 See generally, Ruth A. Miller, The Limits Of Bodily Integrity: Abortion, Adultery, And Rape Legislation In Comparative Perspective at 122-23 (Ashgate 2007), as cited in Bag, Amartya, Adultery and the Indian Penal Code: Analysing the Gender Neutrality of the Law (June 20, 2010). Available at SSRN: https://ssrn.com/abstract $=1627649$ or http://dx.doi.org/10.2139/ssrn.1627649.

66 Daniel Ottosson, Legal Survey on The Countries In The World Having Legal Prohibitions On Sexual Activities Between Consenting Adults In Private (2006), online at http://www.ilga.org/statehomophobia/LGBcri minallaws-Daniel_Ottoson.pdf. 
perceived as morally wrong, the repercussions are tremendous since it threatens family lives and destroys marriages thus leading to increased divorce rates in the society. The consequences of a divorce, especially to children are devastating as this jeopardizes their welfare and greatly affects their upbringing. The present laws governing matters relating to marital infidelity and adultery are seen to be inadequate particularly for the non-Muslims. Like in many western countries, no criminal sanction is imposed either on adultery or marital infidelity in Malaysia. This may be due to the notion that marriage is a personal matter between two parties and any disputes relating to the marriage need to be resolve by the parties themselves. With the increase number of marital infidelity cases and its significant role in causing marriage breakdown, reforming existing law or enacting specific laws against marital infidelity is therefore necessary in order to strengthen protection of the marriage institution. Additionally, research should explore on the need for a clear policy relating to the preservation of the family institution and the need for social awareness programmes on the evils of marital infidelity as well as various ways for couples to effectively deal with this grim problem. 